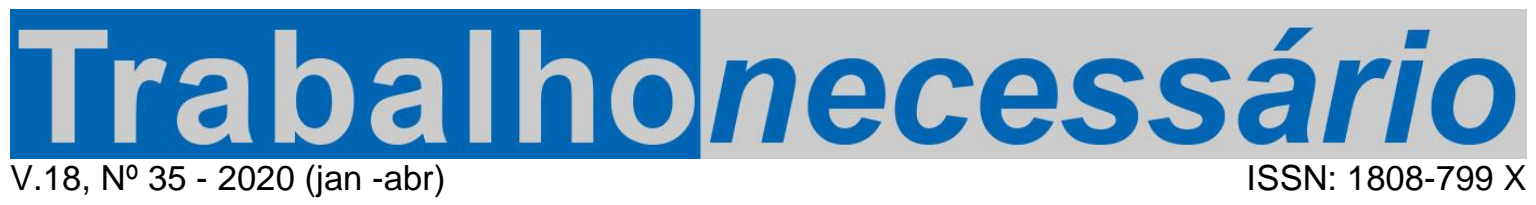

DOI: https://doi.org/10.22409/tn.v18i35.40493

\title{
MEMÓRIAS DE MILITANTES: A GREVE DOS PETROLEIROS DE 1995 $^{1}$
}

Carlos Lucena²

\section{Resumo}

Este artigo tem como objetivo analisar a greve dos petroleiros de 1995. Recupera os embates que construíram a greve, seu desenvolvimento e importância para a luta dos trabalhadores no Brasil. Demonstra as formas opressivas utilizadas pelo Governo Federal, o corpo diretivo da Petrobras e a mídia brasileira para desestabilizar o movimento paredista. Recupera as memórias dos petroleiros e sua compreensão sobre a maior greve dos anos 90 no Brasil.

Palavras-chave: Petrobras; Petroleiros; Greves; Neoliberalismo; Privatização

\section{RECUERDOS DE MILITANTES: LA HUELGA DE PETRÓLEO DE 1995}

\section{Resumen}

Este artículo tiene como objetivo analizar la huelga de petroleros de 1995. Recupera los enfrentamientos que construyeron la huelga, su desarrollo y su importancia para la lucha de los trabajadores en Brasil. Demuestra las formas opresivas utilizadas por el Gobierno Federal, el órgano rector de Petrobras y los medios de comunicación brasileños para desestabilizar el movimiento del muro. Recupera los recuerdos de los petroleros y su comprensión de la huelga más grande de la década de 1990 en Brasil.

Palabras Ilave: Petrobras; Petroleros; Huelgas; Neoliberalismo; Privatización

\section{MEMOIRS OF MILITANTS: THE 1995 OIL STRIKE}

\section{Abstract}

This article aims to analyze the 1995 oil tanker strike. It recovers the clashes that built the strike, its development and its importance for the workers' struggle in Brazil. It demonstrates the oppressive forms used by the Federal Government, Petrobras's governing body, and the Brazilian media to destabilize the wall movement. It recovers the memories of the oil tankers and their understanding of the biggest strike of the 1990 in Brazil.

Keywords: Petrobras; Oil tankers; Strikes; Neoliberalism; Privatization

\footnotetext{
1 Artigo recebido em 14/10/2019. Primeira avaliação em 25/10/2019. Segunda avaliação em 22/11/2019. Aprovado em 06/12/2019. Publicado em 23/01/2020.

2 Pós-doutor em Educação pela Ufscar. Doutor em Filosofia e História da Educação pela Unicamp. Professor Permanente do PPGED/Faced/UFU, linha de pesquisa Trabalho, Sociedade e Educação. Bolsista de Produtividade em Pesquisa 2 do CNPQ. E-mail: carlos.lucena@ufu.br Orcid: https://orcid.org/0000-0003-4383-6812
} 


\section{Introdução}

É um grande desafio retomar as discussões sobre a greve dos petroleiros de 1995, ocorrida entre 3 de maio e 3 de junho de $1995^{3}$, sobre a qual desenvolvemos nossa dissertação de mestrado em educação, defendida em 1996, na Pontifícia Universidade Católica de Campinas. A dissertação foi intitulada como "Aprendendo na luta: a história do sindicato dos petroleiros de Campinas e Paulínia" e publicada posteriormente como livro, com título homônimo, pela Editora Publisher Brasil. Somase também às reflexões o fato de que, nesta greve participei como ator, uma vez que era operador de processamento da Refinaria de Paulínia e, posteriormente, a investiguei como objeto de pesquisa.

Este artigo é um primeiro esboço de um livro que está em desenvolvimento, com previsão de publicação para o final de 2020, no qual submetemos a análise da greve dos petroleiros às contradições nacionais e internacionais. Os bombásticos anos 90 do século XX potencializaram disputas e mudanças econômicas no Brasil, cuja compreensão só é possível a partir da análise da inserção do país no conturbado movimento mundial.

Nossas análises tecem considerações teóricas das motivações da greve a partir da recuperação dos processos de reestruturação produtiva em âmbito mundial, sua implantação na Petrobras e seus impactos na venda da força de trabalho dos petroleiros. Partimos do pressuposto que o processo de reestruturação se explica em um conjunto de mediações expressas nos processos de financeirização das economias e na mundialização do capital.

Esse esforço teórico nos remete à discussão do Livro Terceiro de O Capital, escrito por Marx, e às formas de obtenção de mais-valia absoluta e relativa em sua dinâmica de reprodução do capital composto de juros. Esta afirmação nos permiti analisar a greve como processo de resistência a um amplo processo de subordinação da periferia ao centro do capitalismo, manifesto em privatizações e quebra de monopólios estatais. Isso possibilita, ainda, remetê-la a um nível de mediação expresso nas formas de composição - estatal e privada - do capital nos Bancos

\footnotetext{
${ }^{3} \mathrm{O}$ indicativo para o fim da greve pela FUP ocorreu no dia 2 de junho de 1995. Porém, consideramos o dia 03 de junho de 1995 como encerramento da greve, pois foi marcada pela saída dos trabalhadores da Refinaria Presidente Bernardes em Cubatão, que havia sido ocupada pelos petroleiros. Os trabalhadores saíram em conjunto da refinaria cantando o Hino Nacional Brasileiro.
} 
Centrais e como a decomposição de uma das partes potencializa a instauração de crises econômicas em caráter global que atingem tanto o centro como a periferia do capitalismo 4 .

Contudo, a busca deste nível de mediações tem como condição o desenvolvimento de um processo investigativo centrado, à priori, na recuperação do processo empírico e suas especificidades, que constituem a materialidade investigada enquanto processo humano, real e não arbitrário. Ao fazermos esta afirmação, partimos do princípio investigativo apontado por Marx em "A ideologia Alemã", no qual:

Os pressupostos de que partimos não são arbitrários, nem dogmas. São pressupostos reais de que não se pode fazer abstração a não ser na imaginação. São os indivíduos reais, sua ação e suas condições materiais de vida, tanto aquelas por eles já encontradas, como as produzidas por sua própria ação. Estes pressupostos são, pois, verificáveis por via puramente empírica. $\mathrm{O}$ primeiro pressuposto de toda história humana é naturalmente a existência de indivíduos humanos vivos [...] $\bigcirc$ fato, portanto, é o seguinte: indivíduos determinados, que como produtores atuam de um modo também determinado, estabelecem entre si relações sociais e políticas determinadas. É preciso que, em cada caso particular, a observação empírica coloque necessariamente em relevo - empiricamente e sem qualquer especulação ou mistificação - a conexão entre a estrutura social e política e a produção. A estrutura social e o Estado nascem constantemente do processo de vida de indivíduos determinados, mas destes indivíduos não como podem aparecer na imaginação própria ou alheia, mas tal como realmente são, isto é, tal e como atuam e produzem materialmente e, portanto, tal e como desenvolvem suas atividades sob determinados limites, pressupostos e condições materiais, independentes de sua vontade. (MARX, 2007: 86-87).

Tendo como referência este pressuposto teórico de uma pesquisa em desenvolvimento, abordaremos neste artigo a dimensão material expressa na greve em si, seus bastidores políticos, as estratégias sindicais e as interpretações dos petroleiros.

A greve dos petroleiros, de 1995, constituiu-se no maior movimento de resistência e enfrentamento dos trabalhadores da década de 90 do século XX no

\footnotetext{
${ }^{4}$ Sugerimos a leitura de nosso livro Tempos de destruição: educação, trabalho e indústria do petróleo no Brasil. Campinas: Autores Associados; Uberlândia: EDUFU, 2004. Sugerimos também a leitura de Carlos Lucena; Lurdes Lucena; Robson Luiz de França. A geopolítica internacional do petróleo e o golpe parlamentar no Brasil. In: Carlos Lucena; Fabiane Santana Previtali, Lurdes Lucena. A crise da democracia brasileira. Uberlândia: Navegando Publicações, 2016. Neste livro temos um capítulo que discute a geopolítica internacional do petróleo a partir da mundialização do capital. Disponível em: $<$ https://www.editoranavegando.com/copia-politicas-educacionais- >.
} 
Brasil. Seu contexto histórico se insere em um amplo movimento conservador manifesto pelo então eleito governo de Fernando Henrique Cardoso, do Partido da Social Democracia Brasileira - PSDB - que apostou na quebra dos monopólios estatais e na privatização das empresas estatais como forma de estabilizar a economia nacional em consonância aos trâmites propostos pelo Banco Mundial e o Fundo Monetário Internacional.

O Brasil viveu um amplo processo de transição política. O impeachment de Fernando Collor de Melo e sua sucessão pelo então vice-presidente Itamar Franco, potencializou mudanças econômicas no país. O governo de Itamar teve início sustentado em uma dupla dimensão política. Por um lado, a retomada de um discurso político centrado no nacionalismo populista ${ }^{5}$, por outro lado, a adoção de políticas de estabilização econômica, expressas pelo Plano Real, que negavam os princípios deste mesmo nacionalismo.

A América Latina passava por um expressivo processo de reestruturação econômica e social fundamentada pelos princípios do neoliberalismo 6 . A criação do Plano Brady nos anos 80 do século XX, voltado à renegociação do pagamento da dívida externa através da emissão de títulos internacionais e dolarização da economia, fundamentou pressupostos monetaristas, fornecendo elementos para a criação de planos de estabilização econômica tal qual o Plano Real. O Brasil foi o último país a assinar este acordo no ano de 1994, resultado das negociações em curso desde a eleição do Governo Collor?.

A greve dos petroleiros, de 1995, se inseriu nessa complexa conjuntura nacional e internacional na qual estava em disputa o crescimento dos interesses monetaristas no Brasil e a luta dos trabalhadores em resistência a este processo. Um período marcado pela alta popularidade do governo $\mathrm{FHC}$, sustentado pelos resultados da estabilização econômica em detrimento do processo hiperinflacionário que marcou os anos 80 e início dos 90 do século XX no Brasil.

\footnotetext{
${ }^{5}$ O incentivo governamental para a volta da produção do automóvel Fusca exemplifica esta afirmação.

${ }^{6}$ Sugerimos a leitura de nosso livro: Carlos Lucena. Hayek, liberalismo e formação humana. Campinas: Alínea, 2014

7 Sugerimos a leitura do livro: Antonia Costa Andrade; Carlos Lucena, - Os governos FHC e Lula e a ressignificação do neodesenvolvimentismo: o REUNI - Uberlândia: Navegando Publicações, 2017. Disponível em: < https://www.editoranavegando.com/livro-antonia>.
} 


\section{Prólogo}

A campanha salarial dos petroleiros foi marcada por três greves, sendo duas em setembro e novembro de 1994, e uma em maio de 1995, a maior, até então, de toda a história do movimento sindical petroleiro. Em agosto de 1994, a Federação Única dos Petroleiros (FUP) entregou sua pauta de reivindicações à direção da Petrobras. Entre suas reivindicações, destacavam-se a reposição salarial de 108,36\%, produtividade de $10 \%$, pagamento dos passivos trabalhistas, reposição mensal da inflação pelo Dieese, anistia e reposição do efetivo de trabalhadores nas unidades de exploração e refino. Em contrapartida, a empresa apresentou uma contraproposta de reajuste próximo aos 13\%, índice oficial determinado pelo governo federal, que não repunha as perdas salariais ocorridas até então.

O antagonismo das propostas proporcionou um longo processo de negociação entre as partes, centrado em heterogêneas percepções sobre os rumos econômicos do Brasil. Os petroleiros, representados pela Federação Única dos Petroleiros - FUP, afirmavam que o Plano Real tinha fins "eleitoreiros" objetivando a vitória eleitoral de Fernando Henrique Cardoso (FHC) à Presidência da República. Entendiam o Plano Real como uma estratégia política conjuntural. A direção da estatal apontava problemas de caixa na Petrobras e se dizia impedida de avançar nas negociações por imposição governamental.

A ampla divulgação midiática sobre o risco de perda da estabilidade econômica com a queda do Plano Real colocou parcela considerável da população contra os petroleiros e suas reivindicações. O fomento oriundo do governo Collor dos funcionários públicos e trabalhadores das empresas estatais como "parasitas" da República, em nítida concordância com os fundamentos hayekianos expressos em o "Caminho da Servidão", estavam presentes na sociedade em um crescente processo de alienação política e social. Estava em disputa a cooptação da população para a quebra do monopólio estatal do petróleo, processo este que não foi compreendido em sua totalidade pelos petroleiros e seus representantes, que eram atraídos, gradativamente, para uma armadilha política com severos desdobramentos para o Brasil no futuro.

As negociações não avançaram e, diante do impasse, foi realizada uma plenária na cidade do Rio de Janeiro, no mês de setembro de 1994, onde as principais 
lideranças decidiram decretar uma greve por tempo indeterminado a partir do dia vinte e sete do mesmo mês.

"Começamos as negociações esperando que elas seriam difíceis, mas não esperávamos que elas poderiam ir tão longe. Nas negociações, a Petrobras se dizia de mãos atadas, entendendo que estava um clima de ingerenciabilidade. O clima de insatisfação era muito grande, e eles passavam isso para nós na mesa de negociações, e diziam que apesar das negociações não podiam fazer nada, porque o governo não permitia. A partir de um determinado momento, quando já não poderia haver maiores avanços, ela tentava manter as cláusulas sociais, e isso na visão da empresa era uma questão fora do comum, e na minha posição pessoal, eu acho que era mesmo, pois o projeto que está sendo implantado é para retirar todos as conquistas sociais dos trabalhadores [...]"(Entrevista realizada por este autor com Sérgio Pereira dos Santos, Dirigente sindical do Sindipetro Campinas e Paulínia, em 17 jul. 1995)

A paralisação se concretizou em nível nacional, atingindo $80 \%$ de todo o efetivo da Petrobras. Dois dias após o início do movimento grevista, as principais refinarias interromperam toda a produção de derivados de petróleo. Com o incremento da greve, as lideranças petroleiras buscaram articulações políticas que os favorecessem nas negociações com a direção da estatal e o governo. Contudo, o máximo que conseguiram foi o IPC-R ${ }^{8}$ de $13,54 \%$. Os petroleiros haviam perdido quase $20 \%$ de reposição salarial com a implantação do Plano Real, e, como resultado das negociações e, em estratégia política para desmobilizar os trabalhadores, os dirigentes da estatal ofereciam uma proposta de reposição e a retiravam em seguida, sinalizando para um índice menor.

Nesse primeiro dia já houve conciliação no TST, e na conciliação ele já queria impor o acordo de produção mínima de 30\%, aí enrolamos ele na mesa por quase duas horas, que queríamos negociar com a Petrobrás e o Ministério Público. Ele queria fixar, porque além disso, estabeleceria multa pelo não cumprimento da Lei Judicial, então polemizou [...]" (Entrevista realizada por este autor com Antônio Carlos Spis, Presidente da Federação Única dos Petroleiros, em 17 jul. 1995)

Esta estratégia de negociação visava limitar as reivindicações dos trabalhadores aos patamares empresariais, criando o sentimento de perda constante de um índice de reajuste que não pertencia a sua reivindicação original.

8 Índice de Preço ao Consumidor calculado pelo IBGE. 
A greve se desenvolvia paralelamente à disputa eleitoral para a Presidência da República no Brasil. Um amplo processo de desmoralização dos petroleiros foi desencadeado por parcela da mídia. Os índices apresentados pelo Plano Real referentes à estabilidade econômica e controle da inflação sustentavam os resultados das pesquisas de intenção de voto, que apontavam para a vitória de FHC no primeiro turno das eleições. A paralisação foi divulgada como uma iniciativa desesperada das lideranças sindicais para favorecer o então candidato do Partido dos Trabalhadores PT - Luiz Inácio Lula da Silva. O discurso político midiático se sustentou na afirmação de que os petroleiros adotavam uma estratégia corporativista orquestrada pelo PT, voltada a desestabilizar o Plano Real e prejudicar toda a população brasileira.

Em meio a intensos ataques nos jornais e telejornais, o Tribunal Superior do Trabalho - TST, após três dias de greve, julgou o movimento abusivo, retirando, do acordo coletivo, conquistas históricas dos petroleiros, como a garantia de que a estatal não promoveria dispensas sem justa causa, a redução do índice percentual de dirigentes sindicais com salários pagos pela empresa e a exigência de imediato retorno ao trabalho sob pena de demissão sumária por justa causa dos petroleiros em greve.

Como resposta à sentença proferida por esse julgamento, entendido como ofensivo aos trabalhadores, os petroleiros de todo o país decidiram pela continuidade da greve, desafiando a decisão do TST, uma ação que implicava o risco de demissão sumária de parcela dos trabalhadores. Na prática, os dirigentes sindicais buscaram canais de negociação sustentados pela composição heterogênea dos componentes do Congresso Nacional. Os trabalhadores entendiam que o processo eleitoral em curso poderia favorecê-los, pois tanto a direção da empresa como o governo federal hesitariam em reprimir o movimento, e com isso colocar em risco o resultado do processo sucessório que lhes era favorável.

A redução dos estoques de derivados de petróleo com possibilidade de desabastecimento favoreceu a saída negociada da greve. Por intermédio de Vicentinho, então presidente da Central Única dos Trabalhadores, foi agendada uma reunião, por indicação do presidente Itamar Franco, para o dia 5 de outubro de 1994, à qual, além dele, participaram 4 ministros de Estado, sendo esses, Delcídio Gomes (Minas e Energia), Mauro Durante (Secretário Chefe da Presidência), Marcelo Pimentel (Trabalho) e Ciro Gomes (Fazenda). Como resultado das negociações que 
puseram fim à greve, foi feito um acordo que se chamou "Entendimento de Juiz de Fora", garantindo a não realização de demissões e o pagamento, de forma parcelada, dos passivos econômicos oriundos do Plano Bresser. O termo de entendimento garantia a anistia aos dirigentes punidos no governo Collor, a criação de uma comissão para discutir os passivos trabalhistas e o pagamento das horas extras turno decorrente da implantação do turno de seis horas na Constituição de 1988 em vinte e cinco parcelas e nova negociação das cláusulas sociais.

\begin{abstract}
"O Itamar estava com uma lista de demissões embaixo do braço, e eu falei para ele que se puxasse a lista, não iria negociar. Aí ele falou que ninguém queria destruir o sindicato. Tem que ter respeito à greve. A gente começou a conversar, que retomaria as discussões com a empresa, inclusive das cláusulas econômicas. Suspendemos a greve no dia seis de outubro, a categoria acompanhou essa suspensão sem problemas, porque na época, a gente já não tinha na greve São José, Espírito Santo e Rio Grande do Sul. Ela não estava fortalecida para uma continuidade de enfrentamento. Era um bom acordo, não teve assinatura, segundo o Presidente, ele tinha fé pública, acabaria a reunião, nós falaríamos com a imprensa, isto aconteceu, teve uma coletiva com a imprensa depois da reunião [...]" (Entrevista realizada por este autor com Antônio Carlos Spis, Presidente da Federação Única dos Petroleiros, em 17 jul. 1995)
\end{abstract}

Contudo, após nove dias do término da greve, surgiram rumores que a direção da Petrobras não cumpriria o acordo em virtude de não ter participado das negociações. A partir daí, iniciou-se uma nova mobilização das bases e pressão da direção da FUP para o seu cumprimento. Com a ameaça de uma nova greve, o Governo Federal recuou, propondo um acordo intermediado pelo Ministro Delcídio Gomes, no dia dez de novembro de 1994, que garantia o pagamento dos passivos do Plano Bresser em duas parcelas, sendo a primeira em dezembro de 1994, e a outra em janeiro de 1995. Propôs a conversibilidade do adiantamento do $13^{\circ}$ salário pela URV$^{9}$ do dia trinta de junho de 1994, significando $80 \%$ de reajuste salarial e reintegração dos itens de pauta cortados pelo TST.

"Aí deu uma polêmica, em uma destas reuniões que nós conversamos com o Ministério do Trabalho, com o Pimentel e depois com o Ministério das Minas e Energia, fomos para o Ministério com o Delcídio, aí apareceu o Beni Veras. A reunião começou as nove horas da manhã, terminou as duas horas da manhã do dia dez, aí saiu o acordo chamado termo de acordo, que assinou eu e Delcídio, o

9 Unidade Real de Valor 
Ministério das Minas e Energia assina pela Petrobras, e o Pimentel. Como ela foi até as duas da manhã, não estava mais presente, mas ele participava da redação das cláusulas pelo telefone. Uma cláusula ligava para o Ciro, outra cláusula para o Marcelo Pimentel. Eles participaram da elaboração deste acordo, quem datilografou este acordo foi o advogado da Petrobras e o Clotário, aí assinaram e não houve greve [...]" (Entrevista realizada por este autor com Antônio Carlos Spis, Presidente da Federação Única dos Petroleiros, em 17 jul. 1995)

O processo eleitoral chegou ao final com a vitória de FHC do PSDB em primeiro turno para a presidência da República. Esta vitória foi acompanhada pela eleição da maior parte dos Governadores de estado pelos partidos aliados e a maioria no Congresso Nacional. Com a composição de um novo corpo diretivo em âmbito nacional, a relação política com os petroleiros se acirrou.

Nos bastidores governamentais surgiram rumores que o governo federal não cumpriria o acordo que ele mesmo propusera. A argumentação era que o acordo assinado não era válido, pois um dos Ministros de Estado não o havia assinado. Ao mesmo tempo, o TST revogou o enunciado que garantia como perdas salariais, os passivos do Plano Bresser. Os ministros da Fazenda, Ciro Gomes, e do Planejamento, Beni Veras, pronunciaram publicamente que não aceitariam o acordo final negociado com os petroleiros. O argumento era que se o governo federal garantisse aos petroleiros a reposição das perdas passadas e, principalmente, a atualização pela URV do dia 30 de junho da parcela de antecipação do $13^{\circ}$ salário, todas as estatais reivindicariam o mesmo tratamento.

\footnotetext{
"As negociações se deram até a madrugada, e o Marcelo Pimentel saiu antes do término por problemas familiares. Mas na verdade, ele não queria se comprometer e assinar o que estava sendo discutido lá. Pois na verdade, ela favorecia aos trabalhadores, pois eles estavam dando passivos trabalhistas, era uma alternativa. O Delcídio Gomes concordou com isso, pois estava dando dois salários sem greve, então era um acordo muito bom. O Marcelo Pimentel percebeu isso, então ele pediu para sair, e só por isso não assinou, porque senão teria assinado. Quando no dia seguinte, nós levamos o acordo para ele assinar, ele disse que a poeira havia levantado, que estava meio assim com a questão do Plano Bresser. Então eu assino daqui uns quinze dias, não venha assim, que eu não vou assinar não. $\mathrm{Na}$ verdade, ele deve ter feito contato com a equipe econômica e eles disseram para cancelar". (Entrevista realizada por este autor com Sérgio Pereira dos Santos. Dirigente sindical do Sindicato dos Petroleiros de Campinas e Paulínia em 17 jul. 1995)
} 
A quebra do acordo foi imediata. Como resposta, os petroleiros iniciaram uma nova greve em vinte e três de outubro de 1994. Dois dias depois, horas antes da reunião de conciliação no TST em Brasília, a direção da Petrobras apresentou uma nova contraproposta. A assinatura de um acordo visando um aumento nas faixas salariais (referências utilizadas para os cargos exercidos e tempo na função), que garantia em média de 12 a 18\% de reposição salarial, em troca dos outros benefícios econômicos propostos no acordo anterior. A mobilização não era grande e o acordo de interníveis interessava aos trabalhadores.

\begin{abstract}
"Nós temos uma avaliação crítica que a gente se precipitou um pouco, não deveria ter pego o protocolo, porque durante a conciliação, eu recebi um telefonema que estava sendo feito o acordo. No meu celular o Rennó ${ }^{10}$ falou com o cara da empresa. Nós solicitamos a suspensão da audiência para pegar a cópia deste documento pelo Fax, para ver se dava para aceitar ou não. Aí, de comum acordo, Petrobras e trabalhadores suspenderam a audiência de conciliação devido a possibilidade de acordo“. (Entrevista realizada por este autor com Antônio Carlos Spis, Presidente da Federação Única dos Petroleiros, em 17 jul. 1995)
\end{abstract}

Os trabalhadores avaliaram que passadas as eleições, mantendo uma greve que não tinha tanta mobilização, o TST agiria com truculência contra o movimento. Por outro lado, existia um acordo assinado pela direção da empresa, que de certa forma favorecia a ambos os lados, pois, por um lado, a Petrobras se assumia como ator na negociação e, por outro lado, os petroleiros obteriam uma vitória política ao "desconsiderar" as decisões do TST.

Contudo, o acordo proposto não foi cumprido. O governo federal provavelmente se arrependera de intermediar publicamente as negociações com os petroleiros. A quebra de acordo, sucedido pela proposta de outro que não viria a ser cumprido, ação que se repetiu nas negociações com os trabalhadores das demais Empresas Estatais Brasileiras, constituiu-se em uma ação para ganhar tempo para o início do novo governo e desgastar e desmobilizar os petroleiros. O mandato de Itamar estava no final e suas promessas não teriam como ser cobradas. Estavam colocados todos os elementos para a construção do maior movimento paredista da década de 1990 no Brasil, a greve dos petroleiros de 1995.

${ }^{10}$ Joel Mendes Rennó, Presidente da Petrobrás entre 1992 e 1999. 


\section{A greve dos petroleiros de 1995}

Com a definição da nova data para a paralisação, três de maio de 1995, as expectativas dos petroleiros em nível nacional eram heterogêneas. Uma parcela entendia que ela duraria poucos dias, resolvendo-se o impasse através da negociação. Outra, que a greve poderia ser longa, transformando-se em uma queda de braço com o Governo Federal fortalecido pela vitória nas eleições e a efetividade do Plano Real. Ao mesmo tempo, as lideranças petroleiras negociavam no interior da Central Única dos Trabalhadores a construção de uma greve unificada que fizesse frente a conjuntura existente. A união de diferentes categorias profissionais fortaleceria o movimento paredista, aumentando o poder de barganha dos trabalhadores.

As principais reivindicações apresentadas à direção da Petrobras foram 0 cumprimento do acordo assinado em vinte e cinco de novembro de noventa e quatro, reposição das perdas salariais pelo índice do custo de vida do Dieese (setembro de noventa e quatro a abril de noventa e cinco) equivalente a $26,63 \%$, reintegração de todos os demitidos que participaram da greve anterior, flexibilização das normas e multifunções, contra o desconto dos dias parados por participação em movimentos sindicais e a recomposição de efetivos através de concurso público.

A negativa da direção da empresa em negociar os pontos citados no parágrafo anterior proporcionou o início da paralisação, à exceção de Manaus e Minas Gerais. Os petroleiros que estavam nos turnos de trabalho pararam de se alimentar e dormir, como forma de forçar as gerências locais a assumir a parada da produção. Esta ação dos trabalhadores se dava em virtude das refinarias, poços de exploração e plataformas marítimas se enquadrarem como setor essencial no Brasil. Caso parassem a produção, os petroleiros em serviço ficariam expostos a possíveis retaliações da direção da empresa.

Com o início da paralisação, o TST determinou que as unidades da Petrobras mantivessem uma produção mínima de 30\% em todo o país, uma determinação difícil de ser cumprida em virtude da complexidade do processo produtivo. A manutenção de $30 \%$ nos serviços essenciais foi criada inicialmente para as paralisações no transporte coletivo para garantir minimamente o transporte da população. Na indústria do Petróleo, isso não é tão simples assim. Por razões técnicas, uma unidade de 
processo não consegue funcionar com 30\% da capacidade produtiva, e muito menos quanto ao número de pessoal para operá-la. Sem a existência de uma lei específica, que determinasse o que é produção mínima nessa atividade, ambas as partes não chegavam a um acordo. A direção da Estatal propôs que as unidades deveriam funcionar normalmente, operadas por um efetivo de funcionários superior ao habitual. Os dirigentes sindicais afirmavam que as refinarias deveriam anunciar o volume dos seus estoques de combustíveis, paralisando a produção e bombeando uma cota mínima de derivados para garantir o abastecimento da população e dos Hospitais. A produção só deveria ser retomada mediante a comprovação pela direção da Petrobras de baixos estoques de combustíveis.

Sem acordo entre as partes, dois dias após o início da greve, toda a produção das unidades da Petrobras foi paralisada, visto que os operadores de refinaria estavam sem condições físicas para exercer suas atividades.

A greve crescia com a adesão dos eletricitários e parcela do funcionalismo federal. Ao mesmo tempo, teve início uma forte propaganda midiática contra os petroleiros. Além de inimigos do Plano Real, foram caracterizados como instrumentos da CUT e do PT para acabar com a reforma da Constituição e a aprovação do fim dos monopólios da União. A pauta de reivindicações e as quebras dos acordos assinados não eram divulgados pela mídia. O objetivo era caracterizar o monopólio estatal do petróleo como um privilégio restrito aos petroleiros, visando, com isso, conseguir apoio da população ao projeto neoliberal de abertura da economia ao capital internacional. Ao mesmo tempo, o anúncio constante da provável falta de gasolina e gás de cozinha fez crescer o pânico na população.

No dia seis de maio, com a realização da reunião de conciliação do TST, surgiram esperanças dos dirigentes para o final do impasse. Os advogados da Petrobras não realizaram uma boa defesa quanto a descaracterização do acordo e, mesmo sem um entendimento entre as partes, o Ministério Público emitiu um parecer considerando o acordo legal e a greve abusiva.

A adesão era grande em todas as unidades do país, quando cerca de trezentos petroleiros ocuparam a Refinaria Presidente Bernardes em Cubatão, assumindo o controle da produção. Em Paulínia foram demitidos dois funcionários, demissões estas que foram usadas para negociar a volta em operação de uma das unidades de produção de derivados, o que foi aceito pelo sindicato. 
Com a definição da data do julgamento para três dias após a conciliação, a expectativa dos petroleiros era que o resultado fosse semelhante ao parecer do Ministério Público, o que não aconteceu. O Tribunal Superior do Trabalho julgou abusiva a greve dos petroleiros e considerou inválido o acordo trabalhista assinado em novembro entre o governo e a Federação Única dos Petroleiros. Determinou ainda a imediata volta ao trabalho, autorizando a demissão por justa causa dos grevistas, o desconto dos dias parados e fixou multa de cem mil reais por dia parado a cada um dos sindicatos que organizavam a greve. Entre os doze juízes do trabalho, em relação a abusividade, onze foram favoráveis e um contra e em relação ao acordo assinado, nove pela não validade e três para que fosse mantido.

"Nós fizemos um trabalho de bastidores, juiz por juiz, e nós percebemos que o julgamento iria ser político, e isso facilitou que 0 movimento continuasse forte. E no início, a gente conseguiu passar para a sociedade que tinha um acordo, deixando claro para a imprensa. A partir daí, a greve tomou um caráter político, pois o Fernando Henrique mostrou a sua face, burlando a Justiça, e fazendo tudo o que fosse necessário para impor uma derrota para a classe trabalhadora em geral. Até o presidente do TST, que na conciliação era favorável ao cumprimento do acordo, mas, na hora do julgamento, - Pazzianotto argumentou que a assinatura do Superintendente adjunto da empresa não tinha valor, o que era um absurdo, mudando até o voto do presidente". (Entrevista realizada por este autor com Sérgio Pereira dos Santos dirigente sindical petroleiro do Sindipetro Campinas e Paulínia em 17 jul. 1995)

A reação foi imediata pela continuidade da greve ignorando a decisão do TST. A paralisação assumiu um caráter de contestação à política de $\mathrm{FHC}$, colocando em cheque a "neutralidade" do TST. Os petroleiros compreenderam que o TST era um instrumento político tendendo aos interesses do Estado e da burguesia nacional.

A revolta e indignação cresceu nas bases, bem como a crítica fomentada pela mídia na sociedade. Os petroleiros resistiam através da solidariedade ${ }^{11}$ à crescente

\footnotetext{
${ }_{11}$ A propósito, destacamos que essa categoria profissional possuía características peculiares que a distinguiam dos trabalhadores de outros ramos produtivos. A periculosidade inerente à atividade, $e$ as jornadas de turno que implicavam em uma redefinição da lógica do tempo colocando aos petroleiros uma concepção de dependência mútua que se misturava ao exercício das atividades laborais. Este entendimento se manifestava na construção das lutas sindicais. Um sólido trabalho de base construído por décadas pelos dirigentes sindicais mais experientes que formavam os mais novos, colocavam aos petroleiros uma noção de "honra" para a participação dos movimentos sindicais. Aquele que das greves se recusava a participar era entendido como um traidor da categoria, um pária no chão da fábrica que era desprezado por todos os outros trabalhadores. Ninguém Ihe dirigia a palavra, todos se recusavam a fazer suas refeições próximos a ele. As condições de trabalho e sua periculosidade punham em risco a vida de um trabalhador, sendo o trabalho coletivo e a relação entre os petroleiros condição objetiva
} 
pressão midiática, do governo federal e da direção da Petrobras. A repressão cresceu com a instauração de novas demissões. Dois dias após o julgamento foi divulgada a primeira lista, constando vinte e cinco demitidos, entre eles, Antônio Carlos Spis, coordenador da FUP. No dia seguinte, mais trinta e quatro demissões, sendo cinco petroleiros da Replan em Paulínia e, entre eles, três dirigentes sindicais. Ao mesmo tempo, a mídia intensificou os ataques à greve, anunciando, sistematicamente, a eminente falta de combustíveis.

As distribuidoras de gás de cozinha retiraram os caminhões das ruas, formando grandes filas para a obtenção do produto. Por sua vez, a direção da Petrobras não forneceu os números de estoque e o pânico do desabastecimento cresceu na população. Os sindicalistas desconfiaram desta manobra, mas não conseguiam espaço na imprensa para a denúncia. Em Santos, o prefeito David Capistrano, filiado ao Partido dos Trabalhadores, mandou realizar uma vistoria surpresa nas distribuidoras e constatou que não havia falta de gás de cozinha, determinando que os caminhões fossem às ruas. A propaganda governamental foi descoberta, sem, porém, quase nenhuma divulgação dos meios de comunicação.

O relatório do Tribunal de Contas da União posterior à greve comprovou que não houve desabastecimento, tal qual demonstra o enunciado a seguir:

"Quanto à distribuição, foi verificado que a queda nos volumes de
derivados entregues às distribuidoras, com exceção da nafta, não foi
superior a $16,5 \%$ no mês de maio, com tendência conforme dados
preliminares obtidos, à normalização no mês seguinte. Em razão
disso, observa o Grupo Auditor, percebe-se claramente que há
indícios de que as distribuidoras retiveram produtos,
especulativamente, principalmente o GLP (gás de cozinha) a a
gasolina, pois a redução havida na distribuição não seria suficiente
para causar os contratempos verificados nas grandes cidades, com a

em que um poderia salvar a vida do outro. O petroleiro que não participava da greve era visto como um "covarde" desprovido de "solidariedade", um "pelego" que não tinha coragem de participar de uma greve, quanto mais salvar a vida de seu colega de trabalho. Logo, ele não era digno da amizade de ninguém.

No desenrolar da greve, no dia 15 de maio de 1995, ocorreu a inesperada morte de meu pai com 53 anos de idade. O desenlace foi uma surpresa, visto que ele não apresentava problema grave de saúde. Um derrame cerebral tirou sua vida em poucos minutos. Foi aí que vivenciei um dos maiores exemplos de solidariedade dos colegas e amigos que comigo estavam em greve. Como estava sem pagamento de salários e reservas econômicas, não tinha condições econômicas para realizar o seu funeral. Os petroleiros que estavam em greve em Paulínia arrecadaram o dinheiro para que eu pudesse comprar o caixão e dar entrada no túmulo. Por ocasião do velório havia mais de 1000 petroleiros ao meu lado, carregando bandeiras de diferentes partidos, principalmente do Partido dos Trabalhadores, algo que me comove até os dias atuais e que exemplifica que a solidariedade é possível nas mais difíceis situações. 
população em busca desses produtos. " (Processo de Auditoria nํ-TC008.237/95-6, do Tribunal de Contas da União) ${ }^{12}$

A greve se estendia ao décimo terceiro dia e as lideranças petroleiras buscavam canais de negociação para a solução do impasse. O Estado não mais negociava com os trabalhadores em greve e nem mesmo aceitou a intermediação da Confederação Nacional dos Bispos do Brasil (CNBB) que se oferecera para intermediar as negociações.

Neste período, havia "[...] mais de trezentos mil trabalhadores grevistas em todo o país. Estão parados, trabalhadores de 25 universidades federais, telefônicos (PR/MS/Campinas/SP), trabalhadores da saúde e previdência de sete estados, bem como as escolas técnicas federais“. (Boletim O Petroleiro 07 jun. 1995)

Como a sentença do TST não foi unânime, a FUP entrou com um recurso, pedindo que o tribunal reconsiderasse sua decisão. Por mais contraditória que ela fosse, as lideranças acreditavam que a categoria tinha expectativas em relação ao TST, pois o mesmo poderia representar uma saída negociada para o impasse. $\mathrm{Na}$ realidade, existia uma negociação nos bastidores políticos para o fim da greve. Caso chegasse a um acordo, o Governo Federal apresentaria uma contraproposta que seria apresentada pelo TST como canal de negociação, evitando o seu desgaste político.

O número de paralisações aumentou, com os funcionários da Petrobras Distribuidora, empresa responsável pela distribuição de derivados de petróleo, aderindo a greve e reduzindo a oferta de combustíveis.

As lideranças governamentais agiam contraditoriamente. Por um lado, recuando diante da pressão dos ruralistas no Congresso ao não enviar um projeto de Lei com medidas para a agricultura, que afetavam o crédito e o renegociação das dívidas. Os ruralistas ameaçavam entrar em regime de obstrução das votações, colocando em "perigo" a votação da emenda do gás canalizado. Por outro, endurecia ainda mais as negociações, autorizando a empresa a fazer mais demissões.

A direção da Petrobras começou a emitir telegramas de "convocação de demissão“, determinando o horário de retorno ao trabalho, cujo não cumprimento

\footnotetext{
${ }^{12}$ Fato que já era, inclusive, de conhecimento da própria Petrobrás, segundo admitiu três anos depois o superintendente de Recursos Humanos da empresa, José Lima Neto: "Não era de interesse da Petrobrás na época acionar as distribuidoras por terem sonegado o gás de cozinha", informou em entrevista ao jornal do DCE da USP. Fonte: <https://www.cut.org.br/noticias/greve-historica-dospetroleiros-completa-15-anos-3b60>. Acesso em: 29 nov. 2019.
} 
acarretaria em automática demissão por justa causa. Aqueles que receberam o telegrama chegavam aflitos à sede do sindicato. A pressão familiar para o retorno ao trabalho era intensa e muitos buscavam o conforto dos colegas de trabalho para a continuidade no movimento. As cartas de demissão e os constantes telefonemas das gerências locais objetivavam afetar o convívio familiar e social, transformando-os em agentes que os pressionariam pela volta ao trabalho.

Ao mesmo tempo, o acordo que se negociava nos bastidores para o término do movimento paredista fracassara.

Logo no início da noite de terça-feira, o comando da 11a Brigada de Infantaria Blindada, com sede em Campinas, recebeu ordem do Comando Militar do Sudeste para desencadear a operação de ocupação da Refinaria de Paulínia. A ordem determinava que às 03 horas da manhã, o efetivo militar e os equipamentos deveriam estar entrando pelos portões da refinaria. Foi o tempo necessário para que o $28^{\circ}$ Batalhão de Infantaria Blindada, uma das principais unidades da Brigada, convocasse os homens que a mais de uma semana estavam preparados para agir. (Jornal Correio Popular, 25 maio 1995)

Foram invadidas também a Recap em Mauá, a Revap em São José dos Campos e a Repar em Araucária no Paraná. Na Replan, em Paulínia, a força do exército contou com cerca de quinhentos soldados armados de metralhadoras e granadas de mão, quinze tanques de guerra, dezenove caminhões, dezessete jipes e cães treinados, que entraram na refinaria sob os olhares de quatro trabalhadores que faziam plantão na portaria principal em nome do sindicato quando da ocupação.

Um longo debate ocorreu nos bastidores políticos petroleiros sobre a continuidade ou não da greve. Para a direção da FUP, a invasão das refinarias oportunizava encerrar o movimento com pretensa vitória política sobre o governo federal que seria acusado de antidemocrático e truculento. Esta era uma proposta que não era aceita pelos petroleiros, especialmente os de Cubatão que, como afirmamos, haviam tomado o controle da produção da refinaria. Luiz Inácio Lula da Silva fez um pronunciamento ${ }^{13}$ sinalizando para o término da greve, temendo o isolamento dos petroleiros, o que foi entendido como traição por parcela da categoria profissional.

${ }^{13}$ Entrevista de Lula ao Jornal Nacional da Rede Globo de Televisão sobre os desdobramentos da greve e os problemas que ela acarretava à população devido à falta de gás de cozinha. 
Um delicado cenário político estava posto. Os petroleiros contavam com o apoio do MST e dos professores das universidades federais que também participavam da greve. A CUT não apontava para a convocação de uma greve geral de apoio à paralisação. A invasão do exército objetivava o fechamento de todo $e$ qualquer canal de negociação. O Presidente da República afirmara publicamente que não intermediaria o conflito. O TST, que já havia julgado a greve abusiva e não reconhecido o acordo, em novo julgamento, dois dias após a ocupação militar, repetiu o resultado do anterior.

Apesar de toda a repressão, com os vencimentos zerados, os petroleiros, em desafio à segunda decisão do TST, decidiram pela continuidade da greve em uma grande assembleia. A estratégia foi a aposta no contato direto com a população nas ruas das cidades brasileiras. Em Campinas, as reações dos transeuntes eram diferenciadas. Uma minoria ficava perplexa quando conferiam 0 varal de contracheques com valores muito abaixo do que a imprensa estava divulgando. Por sua vez, a maioria comparava os vencimentos dos petroleiros com os seus, não entendendo os motivos da greve. Isso se explica no comparativo entre os salários dos petroleiros e dos transeuntes ali presentes, pertencentes a uma parcela de trabalhadores cujos vencimentos não ultrapassavam dois salários mínimos, inferior ao salário dos petroleiros.

[...] as pessoas passavam na rua, amassavam o papel que estávamos entregando e jogavam na gente. Vai trabalhar vagabundo. Em casa não tem gás de cozinha [...] (Entrevista realizada por este autor com Odir Rodrigues Amaral, operador de processamento da refinaria de Paulínia. Petroleiro em greve, em 18 jul. 1995)

As negociações prosseguiam em nível parlamentar sem apresentar resultados positivos aos petroleiros. A Polícia Federal iniciou os inquéritos para apurar se os sindicatos feriam o código penal. Ameaças de demissão e abandono de emprego surgiam no noticiário, visto que a paralisação se aproximava de trinta dias. $O$ índice de retorno ao trabalho cresceu e algumas unidades voltaram a funcionar, diminuindo o ímpeto da greve e sua capacidade de mobilização. Com o refluxo de retorno ao trabalho e um documento assinado pelos parlamentares pela retomada das negociações, a FUP, no dia 02 de junho de 1995, indicou o término do movimento condicionado à retirada de todas as tropas militares das refinarias. 
O término da greve potencializou ações e discursos políticos. Por um lado, a mídia divulgou a derrota total dos petroleiros e a vitória política do governo FHC, condição que o fortaleceria no Congresso Nacional para a aprovação da quebra do monopólio estatal do petróleo e a criação da Agência Nacional do Petróleo. Por outro lado, a própria CUT difundiu a derrota da greve e a destruição dos sindicatos dos petroleiros dada as multas impostas pelo TST.

O que nos chama a atenção foram os indícios que a greve dos petroleiros e o fracasso na conquista de suas reivindicações foram explorados por seguimentos dos próprios trabalhadores como exemplo concreto de que era impossível resistir ao avanço neoliberal. Nesta concepção, a única saída possível era a construção de alternativas de conciliação, condição essencial para uma possível vitória eleitoral no futuro. Esta estratégia potencializou a criação de uma espécie de estigma da destruição dos sindicatos petroleiros, o que na realidade não ocorreu. Os petroleiros construíram alternativas de resistência ao intenso processo repressivo que se seguiu após a greve. Os petroleiros demitidos tiveram seus salários mantidos pelo fundo de greve, transformando-se em dirigentes sindicais sustentados pela categoria profissional, elevando a representação e ação sindical dos trabalhadores. Ocorreu um forte trabalho político de bastidores que levou à readmissão de todos os demitidos durante a greve no ano de 2003 . Todas as demissões, advertências, suspensões e punições foram suspensas.

A ação governamental de retenção das verbas sindicais através do confisco das mensalidades não ocorreu em sua totalidade. Os petroleiros sindicalizados passaram a depositar as suas mensalidades através dos fundos de greve, inviabilizando o seu confisco. Um ato que, por um lado, colocou o Sindicato na clandestinidade e, por outro, garantiu a sua própria sobrevivência. Logo, os sindicatos não foram inviabilizados ou destruídos economicamente, tal qual se divulgou na mídia e em setores críticos da sociedade. Da mesma forma, por anos, os petroleiros barraram e denunciaram os processos de reestruturação produtiva que estavam em curso na Estatal. Estas ações culminaram com as denúncias à priori das precárias condições de trabalho dos petroleiros, às quais, no início dos anos 2000 , chegaram a uma morte a cada quinze dias e culminou com o acidente da Plataforma P-36 na Bacia de Campos ${ }^{14}$.

${ }^{14} \mathrm{Em}$ nosso livro "Tempos de destruição: educação, trabalho e indústria do petróleo no Brasil, demonstramos em detalhes os índices de mortalidade e o acidente na Plataforma P-36 de Petrobrás. 
Existem questões ainda em aberto e que carecem ser investigadas sobre os desdobramentos da greve dos petroleiros de 1995. Sendo o discurso político midiático burguês sobre a derrota total dos petroleiros uma mensagem a todos os trabalhadores do Brasil que não mais deveriam resistir e/ou fazer greves em protesto aos ajustes neoliberais, por que ele foi difundido pela Central Única dos Trabalhadores - CUT - a todas as demais categorias profissionais? Quais os motivos do isolamento político dos petroleiros e os professores da Universidades Federais nos dias finais da greve e a não convocação por parte da CUT de uma greve geral em solidariedade aos grevistas? Estava em jogo a construção de uma alternativa política governamental sustentada na conciliação para o futuro que seria capitaneada por segmentos críticos? Qual o significado do pronunciamento de Lula relativo ao indicativo para o fim da greve após o último julgamento do TST que decretou a abusividade da greve? Um alerta sobre as consequências do isolamento da greve que poderia levar a dezenas de novas demissões, ou um ato de traição, tal qual entendeu parcela dos petroleiros em greve?

\begin{abstract}
"Quando o Lula falou aquilo15, ele falou visualizando que quando o Presidente falou que não iria fazer o que o Itamar fez, o recado que ele passou foi o seguinte, não adianta vir o Vicentinho, não adianta vir ninguém, que eu não vou fazer reunião para resolver este problema, isto é problema deles. Eu não faço reuniões, este foi o recado. A gente entendeu isto, só que não dava para chegar na assembleia e dizer, olha não tem mais saída, só que era muito difícil, poderia ter uma influência dos parlamentares para uma saída para o impasse, não uma solução para o impasse, era diferente. Não tivemos solução até hoje, tivemos saída, foi isso que o Lula falou, ele falou isto para mim inclusive [...]" (Entrevista realizada por este autor com Sílvio José Marques, dirigente sindical dos Sindicato dos Petroleiros de Campinas, em Paulínia, em 22 jul. 1995)
\end{abstract}

A greve dos petroleiros de 1995 representou o maior movimento de resistência dos trabalhadores ao neoliberalismo no Brasil, um movimento paredista que colocou essa categoria profissional e o MST como os principais atores de luta na década em questão.

\title{
Referências
}

ANDRADE, A. C.; LUCENA, C. Os governos FHC e Lula e a ressignificação do neodesenvolvimentismo: o REUNI - Uberlândia: Navegando Publicações, 2017.

${ }^{15}$ Refere-se a uma entrevista de Lula ao Jornal Nacional sobre os desdobramentos da greve e os problemas que ela acarretava à população devido à falta de gás de cozinha. 
BRASIL. Tribunal de Contas da União. Processo de Auditoria no TC-008.237/95-6, 1995.

LUCENA, C. Aprendendo na luta: a história do sindicato dos petroleiros de Campinas e Paulínia. 1996. 126f. Dissertação (Mestrado em Educação), Puccamp, Campinas, 1996.

C. Aprendendo na luta: a história do sindicato dos petroleiros de Campinas e Paulínia. São Paulo: Publisher Brasil, 1996.

. Tempos de destruição: educação, trabalho e indústria do petróleo no Brasil. Campinas: Autores Associados; Uberlândia: EDUFU, 2004.

LUCENA, C.; LUCENA, L.; FRANÇA, R. L. de. A geopolítica internacional do petróleo e o golpe parlamentar no Brasil. In LUCENA, Carlos; PREVITALI, F. S., LUCENA, L. A crise da democracia brasileira. Uberlândia: Navegando Publicações, 2016.

HAYEK, F. O caminho da Servidão. SP: Ed. Globo, 1974.

MARX, K O Capital: crítica da economia política. Livro $3^{\circ}$ Volume VI, tradução Reginaldo Sant' Anna - 3. ed. - São Paulo: Ed. Nova Cultural, 1984.

MARX, K. ENGELS, F. A ideologia alemã: crítica da mais recente filosofia alemã em seus representantes Feuerbach, B. Bauer e Stirner, e do socialismo alemão em seus diferentes profetas (1845-1846). Tradução: Rubens Enderle, Nélio Schneider, Luciano Cavini Martorano. São Paulo/SP: Ed. Boitempo, 2007.

\section{Boletins e jornais}

Boletim O Petroleiro. Paulínia: Sindicato dos Petroleiros de Campinas e Paulínia. 07 jun. 1995.

Jornal Correio Popular, Campinas. 25 maio 1995. 